\title{
NEW BOOKS AND OTHER PUBLICATIONS RECEIVED
}

Agmon, Tamir and Kindleberger, Charles P., ed. Multinationals from Small Countries. Cambridge, MA: The MIT Press, 1978.

Crowe, Kenneth C. America for Sale. Garden City: Doubleday, 1978.

Haanappel, Peter P.C. Ratemaking in International Air Transport: A Legal Analysis of International Air Fares and Rates. Deventer, The Netherlands: Kluwer 1978.

Hutzel, John M. Strategy Formulation in the Multinational Business Environment: A Guide to International Political Forecasting. Institute for Business and Economics Research, San Jose State University, 1978.

Lawriwsky, Michael. Ownership and Control of Australian Corporations. Transnational Corporations Research Project, University of Sydney, 1978.

Newbold, Gerald D.; Buckley, Peter J.; and Thurwell, Jane. Going International. London: Associated Business Press, 1978.

United Nations Economic and Social Council. Transnational Corporations in World Development: A Re-examination, 1978.

Utrecht, Ernst and Short, Kate. Transnational Corporations in South East Asia and the Pacific, vol. 1. Transnational Corporations Research Project, University of Sydney, 1978.

\section{EDITOR'S NOTE}

Book reviews will be selected in the future from the books listed above and from others subsequently received. The listing of a book does not assure a review of the book in JIBS. 